Article

\title{
Sustainable Design: A Case of Environmental and Cost Life Cycle Assessment of a Kitchen Designed for Seniors and Disabled People
}

\author{
Anna Lewandowska ${ }^{1, *}$, Bogdan Branowski ${ }^{2}$, Katarzyna Joachimiak-Lechman ${ }^{1}$, \\ Przemyslaw Kurczewski ${ }^{2}$, Jaroslaw Selech ${ }^{2}$ and Marek Zablocki ${ }^{2}$ \\ 1 Faculty of Commodity Science, Poznan University of Economics and Business, Poznan 61-875, Poland; \\ katarzyna.joachimiak-lechman@ue.poznan.pl \\ 2 Faculty of Machines and Transportation, Poznan University of Technology, Poznan 60-965, Poland; \\ Bogdan.Branowski@put.poznan.pl (B.B.); przemyslaw.kurczewski@put.poznan.pl (P.K.); \\ jaroslaw.selech@put.poznan.pl (J.S.); marek.zablocki@put.poznan.pl (M.Z.) \\ * Correspondence: anna.lewandowska@ue.poznan.pl; Tel.: +48-61-854-3121
}

Received: 28 June 2017; Accepted: 27 July 2017; Published: 29 July 2017

\begin{abstract}
Sustainable production and consumption patterns require a change in approach at the early conceptual stages, i.e., when planning and designing products and services. This article presents an example of sustainable kitchen design aimed at the needs of seniors and people with physical disabilities, which takes into account social, economic, and environmental aspects. The interdisciplinary project team used a variety of traditional design methods such as the identification of requirements using QFD (Quality Function Deployment) and FMEA (Failure Mode Effects Analysis), the development and verification of the technical concepts of the designed objects and their use, the development of construction and technological documentation, assembly drawings of the product architecture and its parts, function cost analysis, virtual and real prototyping, and tools based on the concept of a life cycle such as environmental life cycle assessment (LCA) and life cycle costing (LCC). The analysis of the design solutions from the point of view of several criteria and several life cycle stages shows the complexity of the decision-making process and the difficulties in selecting a clearly favourable solution. Environmentally preferred materials may be difficult for users to accept due to their costs. On the other hand, materials that have a high environmental impact at the production stage may show great potential for final disposal.
\end{abstract}

Keywords: environmental impact; costs effectiveness; life cycle design; disability; kitchen

\section{Introduction}

This article presents the results of life cycle assessment (LCA) and life cycle costing (LCC) analyses performed as part of a project called 'New Product Lines Enhancing Mobility and Accessibility of Environment for Seniors and Disabled (PBS1/A6/5/2012)', which was conducted from 2012 to 2015 by employees of several Polish research centres, including the Poznań University of Technology, the Poznań University of Life Sciences, the Poznań University of Medical Science, and the Poznań University of Economics and Business.

This project was carried out within the context of various scientific and other academic fields, including gerontechnology, rehabilitation techniques, mechanical and material engineering, ergonomics, design, marketing, and environmental science. The fundamental goal of the project was to develop new product lines (furniture, rehabilitation equipment), which considered the specific needs of elderly and disabled people and would be suitable for commercialization in the Polish market. The project team developed new design concepts for kitchen lines, as well as devices for physical 
rehabilitation at home and rehabilitation vehicles. Additionally, methods for testing the parameters of the manipulation zone and human strength were devised [1].

The number of people with health impairments continues to grow due to an ageing population, as well as a global increase in those suffering from chronic diseases that cause disability [2]. The phenomenon of increasingly ageing societies is a result of two factors: a decrease in the birth rate and the prolonging of the average lifespan. Historically, living to an old age was experienced only by a small section of society, whose needs in this regard garnered little attention [3]. Ageing societies, then, are a new phenomenon and require intensified efforts to support the needs of elderly individuals but in a way that can be sustained by the whole society. According to a report prepared by the United Nations (2001), those aged 80 years and over will constitute $4.1 \%$ of the global population by 2050 . In developed regions, however, this age group is expected to form $9.6 \%$ of the population, compared to $3.3 \%$ in under-developed regions. The 'oldest' country in the world will likely be Japan, with $15.1 \%$ of its population to be aged 80 years and over by 2050 . The European average for this age group is projected to rise to $10 \%$ of the overall population in the same period, with the highest forecasts given for Italy (14.1\%), Switzerland (13.9\%), Germany (13.2\%), and Sweden (12.2\%). In North America, the same age group will form $7.7 \%$ of the overall population in 2050, compared with $4.2 \%$ in Asia, $4.1 \%$ in Latin America, and 1.1\% in Africa. When taking those aged 65 years and older into account, this currently constitutes $15.6 \%$ of the global population and $29.2 \%$ of the European population [4].

For societies experiencing demographic phenomena related to ageing and disease, the elderly and disabled population should be included in any design process affecting their quality of life, while the consideration of their individual needs ought not to be limited to medical and rehabilitation products. Designing goods that meet the bespoke needs of elderly and disabled people ought to receive special attention. Given that one-third of society is already of older age, design considerations should not be limited to medical and rehabilitation products. Increasingly, examples are cited in the literature of design processes for non-medical products that take the needs of the elderly into account such as packaging [5-7], electronic and telecommunication devices [8-11], and cars [12,13].

The analysed kitchen design is the result of the cooperation of an interdisciplinary project team. It was decided to use a combination of traditional and environmental design methods and life cycle thinking (LCT) to design the kitchen lines. Design for Environment (DfE), also called Life Cycle Design or Sustainable Design, means that environmental aspects are included in the conceptual stages, i.e., product design and development [14]. The aim of DfE is to combine traditional design criteria (cost, quality and technological availability of materials, aesthetics, functionality, security, etc.) with the criterion of environmental impact [15]. A characteristic feature of modern eco-design is that this impact is calculated with respect to the entire product life cycle. As the cost and environmental aspects are crucial in eco-design, they should be analysed with tools that take into account the life cycle perspective. These tools include LCA and LCC, which can be used universally, for all products and processes. The products differ in terms of construction, manufacturing, function, the mode of fulfilling the function, durability, recyclability, and many other aspects. Most of the aspects play a vital role from the perspective of eco-design and environmental efficiency. Despite this diversity, there are some efforts [16-21] attempting to classify products into groups, where a similarity between life cycles (strictly, the places where the environmental hot spots appear) is the main criterion of classification. As furniture is usually heavy, has a long lifetime (with potential reuse), and has no need for operational energy, it is recognized as a passive and material/manufacture intensive product. The environmental hot spots lie in the processing of resources and materials as well as in the manufacturing of furniture [19-21].

LCA $[22,23]$ and LCC $[24,25]$ were used to assess the environmental impacts and costs for different design concepts of the kitchen. For the purpose of integrating LCC with LCA, an environmental Life Cycle Costing (e-LCC or LCA-based LCC) has been developed, and this topic became meaningful in the theoretical considerations as well in the practical context [26-34]. 
It has been found that there is no other publication within the available literature that presents research into the design work for kitchens produced for the elderly and people with motor impairment, which simultaneously uses traditional and environmental design methods. There are publications that refer to the design of bespoke kitchen lines for elderly and/or disabled people (e.g., [35-41]), but none of them consider the environmental aspects of the respective processes. On the other hand, there are publications that deal with kitchen eco-design but without any specific consideration of the needs of elderly and/or disabled people, e.g., [42-45].

\section{Materials and Methods}

\subsection{Kitchen Design}

This article presents the results of an environmental and cost life cycle assessment for different variants of the kitchen intended for seniors and the physically disabled. In this kitchen design, dozens of structural and functional solutions have been used, addressing the needs of the elderly and the physically disabled. They relate to the spatial arrangement of the kitchen, the design, and the functionality of the furniture and accessories. Below are some of these solutions:

- A single space: the kitchen is connected with the living room. The use of kitchen islands or peninsulas functionally separates different spaces. There is a continuous worktop. The order of furniture units is adapted to the direction in which a person in a wheelchair moves;

- Room for wheelchair manoeuvres (diameter $150 \mathrm{~cm}$ );

- The rooms are additionally lit by sunlight (a window in the room);

- Contrasting colours of the floor and the furniture;

- Non-slip floor;

- The furniture is $140 \mathrm{~cm}$ high and ensures the visibility of the cabinets' contents;

- Installation of household appliances at a minimum height of $29 \mathrm{~cm}$ above the floor level;

- Drawers are equipped with a mechanical opening support system. There are push-to-open and full extension drawers and push-to-open shelves in cabinets (except for the refrigerator and the dishwasher); the shelves are equipped with an electrically assisted opening system;

- Front finish protects from wheelchair or crutch scratches;

- Flatware trays in the drawers are adapted to the capabilities of users and their strength; the heaviest items are closest to the axis of their body;

- Handles can change their positions and angles.

The kitchen has been designed for five people, including at least one with limited mobility. The kitchen can be described as having a high standard because it is intended for a detached house with an area of $263 \mathrm{~m}^{2}$. It is an open kitchen with an area of $25 \mathrm{~m}^{2}$ (Figure 1).

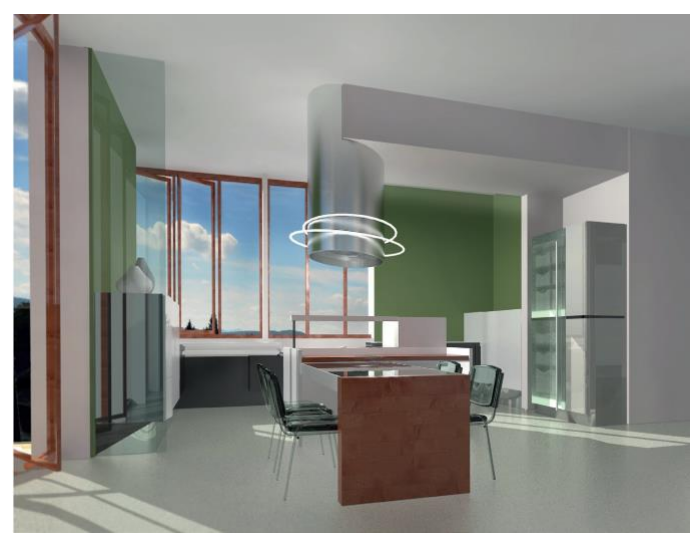

Figure 1. Visualization of the kitchen [2]. 
The kitchen consists of 16 furniture units (13 types because three of these types are double). The mass of all the furniture is $924 \mathrm{~kg}$; the two storage cabinets are the heaviest $(14 \%)$, followed by two low corner cabinets $(15 \%)$, two low storage cabinets $(11 \%)$, the worktop $(11 \%)$, and a modular cupboard $(10 \%)$. The furniture arrangement in the kitchen is presented in Figure 2. From the point of view of the construction materials, the composition of the kitchen furniture in the baseline scenario is as follows: wood $(0.02 \%)$, wood-based materials $(88 \%)$, steel $(9.8 \%)$, plastics $(1.5 \%)$, and aluminium $(0.7 \%)$.

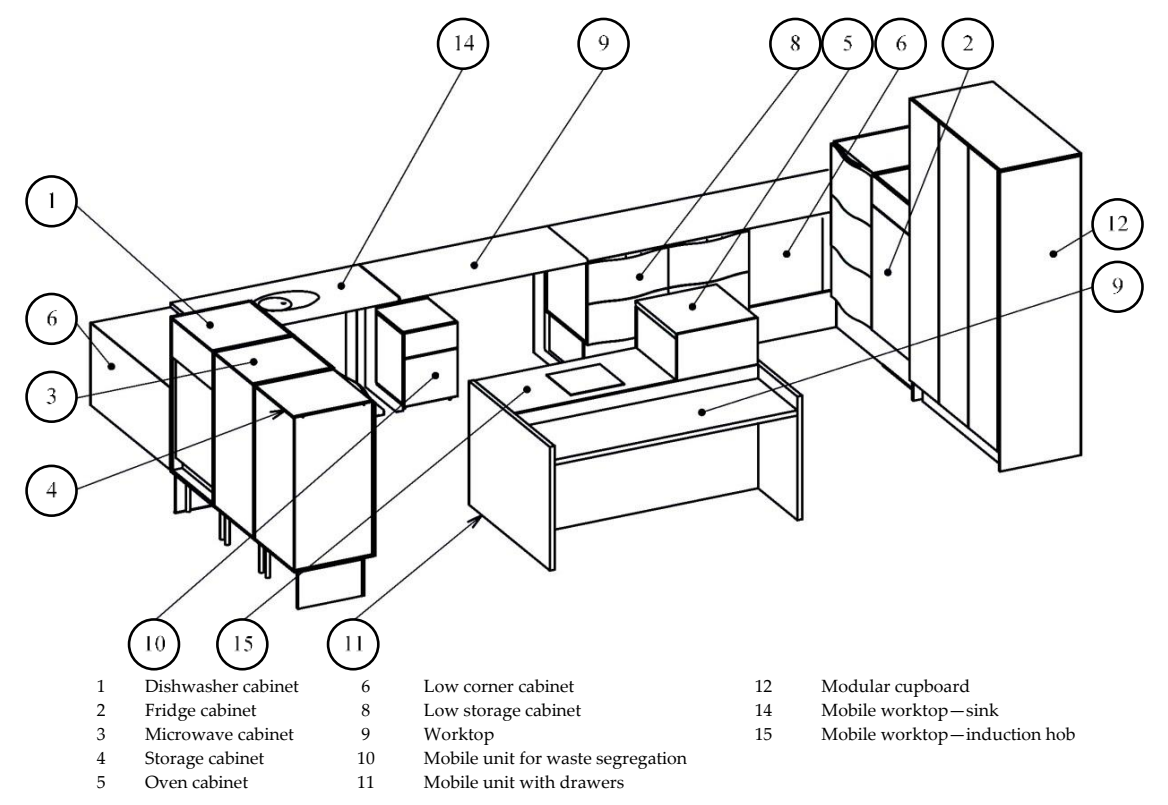

Figure 2. Furniture arrangement in the kitchen [2].

\subsection{Life Cycle Assessment (LCA) and Life Cycle Costing (LCC)_General Methodology}

The environmental impact was assessed by using the Impact 2002+ Life Cycle Impact Assessment method, which includes the following impact categories: non-renewable energy, mineral extraction, land occupation, carcinogens, non-carcinogens respiratory inorganics, ionizing radiation, ozone layer depletion, respiratory organics, aquatic ecotoxicity, terrestrial ecotoxicity, terrestrial acidification/ nutrification, aquatic acidification, aquatic eutrophication, global warming, and non-renewable energy [46]. This method was chosen because it combines midpoint and endpoint approaches. On the one hand, it enables the analysis of the characterization results, wherein the environmental impact is modelled using midpoint indicators; on the other hand, it allows a single result in the form of a single score expressed in points $(\mathrm{Pt})$ to be obtained. Thanks to the cumulative result, designers can, in a quick and transparent manner, identify which materials and components are the main sources of a negative environmental impact. Due to the use of LCA at the design stage, in this article, special emphasis was placed on presenting the LCIA results as a single score, while the characterization results are commented on in the 'Discussion' section. The LCIA results are presented in the following order: life cycle stages, furniture units, materials, and components (the latter only for selected furniture units).

As for the LCC, the costs were estimated from the point of view of the furniture user. The analysis included the purchase price of the furniture accessories and construction materials, transportation, water, detergents, labour, and market retail prices of waste resale in Poland in 2015. Due to the 10-year lifespan of the furniture, LCC analysis was carried out in two variants: without the discounting of costs and with discounting. Costs that occur at different points in time over a study period cannot be directly summed up because they have different values. The discount rate is the rate that is used in the calculation of the present value and it enables costs at different points in time to be compared. The adopted parameters included a real discount rate of $5 \%$, a discount rate of $7.72 \%$ for the costs of use (10 years) and $0.61 \%$ for final disposal (after 10 years of use). It was assumed that the stages of the 
purchase, transportation, and installation would be carried out shortly after each other, and therefore they were not discounted.

\subsection{Goal and Scope Definition}

The main objective of this study is to determine the potential environmental impact and costs associated with the entire life cycle of the designed kitchen. Specific objectives of the study are to:

- Identify which stage of the life cycle of the analysed kitchen furniture generates the greatest negative environmental impact and costs;

- Identify which module and group of components are the main sources of the costs and negative environmental impact in the life cycle of the analysed kitchen furniture;

- Compare different variants of the kitchen with respect to costs and environmental impact.

The starting point for any LCA and LCC is to identify the functional unit of the analysed object. In the case of furniture, traditional functions are likely to include the provision of working areas for food preparation and cleaning, storage for food products, and space for kitchen equipment, as well as aesthetic and social functions (taking into account that the kitchen plays an important role within the organization of family life). In addition to these traditional assumptions, it is also imperative that the furniture relevant to this project is concerned, with regard to its functionality, with meeting the needs of the elderly and those with motor impairment. With this in mind, a functional unit for the purposes of this particular LCA was defined as able to 'provide, for a period of 10 years, a storage area and working space necessary for food preparation and simple kitchen activities for a five-person household, where at least one user is elderly or a person who has experienced motor impairments'. A function described by the functional unit can be fulfilled by various design solutions in terms of the materials used for manufacturing the furniture modules. Since the fronts and worktops strongly affect the appearance and visual character of the kitchen, various construction materials for these elements have been included in the comparison. They differed in the origin of the base material (wood versus stone), mass, durability, and costs (purchasing and maintenance).

The LCA and LCC analyses were conducted in reference to the following life cycle stages of kitchen furniture: the production of materials and construction elements; the transportation of materials and construction elements to the user; furniture installation at the users' accommodation; the use of furniture; and the final disposal of used furniture.

\subsection{Life Cycle Inventory}

For the purposes of gathering inventory data, a number of rules were imposed, the most important of which were as follows.

- Collating the LCIA on the basis of production data that refer to each of the materials used in construction, rather than on the basis of producing specific elements (e.g., the LCA analysis of a handle unit was performed for the production of $0.02 \mathrm{~g}$ of aluminium as a construction material not for the production of the handle itself). It also refers to fronts and worktops made of wood, for which the LCA calculation has been based on the raw material requirement instead of the final product (furniture). This assembly-related approach for gathering inventory data is the most important simplification made in the study, which would make the final LCA results slightly underestimated. As the most popular generic LCA databases do not include data on the production of furniture itself, specific LCA and LCC data would have to be collected from manufacturers, which would make the analysis much more time-consuming.

- Due to the lack of necessary data, the furniture packaging and furniture accessories were excluded from the Life Cycle Inventory and Life Cycle Impact Assessment analyses;

- Due to the lack of necessary data referring to the dimensions and material content, the following elements were excluded from the LCA analysis: the corner shelf with a mechanism (used in the low corner cabinet SN120/90) and the modular cupboard mechanism; 
- The assumed lifetime for the kitchen furniture accessories and the specified construction elements is 10 years, in line with the manufacturers' lifetime guarantee. After that period of time, it is expected that the entire set of kitchen furniture may be replaced, which then becomes a waste management issue;

- Only furniture was the subject of analysis; kitchen equipment elements (e.g., household appliances) were not included;

- The furniture was transported to the user by a van with a total load up to $3.5 \mathrm{t}$ (van);

- After the end of the life of the granite, it was assumed that it was passed to a producer of aggregates for reuse. Due to the lack of data about the process of granite reuse, only its transportation was included (distance: $100 \mathrm{~km}$ );

- Costs were determined on the basis of prices in Poland at the time of the study (July/August 2015) and converted from PLN into EUR (exchange rate 4.38 PLN/1€). The transportation costs included the purchase price of fuel and the driver's wage (by the rate per working hour). The installation time, power consumption resulting from the use of power tools, and the installers' remuneration were determined on the basis of interviews with people specializing in the installation of kitchen furniture. Scenarios of the final disposal were adopted in accordance with the practice of dealing with these types of waste under the current Polish conditions in 2015. The price of waste sale to waste disposal entities (waste incinerator, recycler) was adopted based on the market prices of waste management in Poland in 2015. The costs were determined from the point of view of the furniture user (market prices of furniture components and accessories, transportation costs by retail rates, the remuneration of installers by the retail rate per working hour, the cost of purchasing water for households, market prices of detergents and preservatives, prices of waste resale to a recycler or a waste incinerator). In scenario ALT2b, half of the granite price has been used; however, a better idea could have been to use a price based on selling used granite. As this kind of information was not available, the first solution has been chosen.

As a starting point for the life cycle inventory analysis, a table was prepared for each furniture unit, detailing all components and accessories. These tables included the name of each unit, the type of material, the mass of each unit, and cost information (purchase price). Furthermore, the tables were prepared including transportation to customers, installation, and final disposal. The analysis involved the following scenarios for the use of different materials for fronts and worktops:

- Basic variant (BASE): furniture fronts and worktops are made of wood-based boards (fronts: lacquered Medium Density Fibreboard (restoration by lacquering once a year); worktop: high-pressure laminate (HPL) board; the lifetime of all the furniture is 10 years);

- Alternative variant 1 (ALT1): furniture fronts and worktops are made of solid hardwood (restoration by oiling cabinet fronts and worktops once a year; the lifetime of all the furniture is 10 years);

- Alternative variant 2a (ALT2): furniture fronts are made of wood-based boards (lacquered MDF, their lifetime is 10 years, restoration by lacquering fronts once a year), the worktops are made of granite (impregnation of the granite worktop once a year; the lifetime of all the furniture is 10 years);

- Alternative variant $2 b$ (ALT2b): furniture fronts are made of wood-based boards (lacquered MDF, the lifetime of all the furniture, except for the granite worktop, is 10 years, restoration by lacquering the fronts once a year), granite worktops (impregnation of granite once a year; lifetime is 20 years; additional legs for cabinets, on which granite worktops are placed). Since a 10-year time limit was assumed for the functional unit and the lifetime of the granite worktops in ALT2b was assumed to be 20 years, in this scenario, it was assumed that only half of the granite would be needed to fill the functional unit. For this reason, in ALT2b, it was assumed that $50 \%$ of the granite would be produced and subjected to final disposal. This treatment was aimed at showing the potential environmental benefit resulting from the extended lifetime of this material. 
Due to its high durability, granite could be theoretically used for much longer than 10 years. This means that, after 10 years of its first use, it would not become waste, but it could be a part of another product system (e.g., another kitchen), thus fulfilling its function for the next 10 years. This would eliminate the need to produce new granite, and the related impacts can be treated as avoided burdens. However, this would not eliminate the transportation, installation, and the use of the entire surface of the granite worktops, which in fact are doubled (in the analysed kitchen and the alternative kitchen, in which this granite will be hypothetically used over the next 10 years after the 10 years of its first use). This means that half of the granite can be assigned to the analysed kitchen and another half to the alternative product system. Thus, from the point of view of the final result calculated for the entire life cycle, it does not matter if the input production is decreased by $50 \%$ or if the production impacts are modelled as avoided burdens in the amount of $50 \%$ of the granite. Accordingly, it was assumed to assign $50 \%$ of the mass of granite waste to the analysed kitchen and the other half to the alternative system. In summary, in the LCA and LCC analyses, the consumption of granite was modelled in scenario ALT2b as follows: the production was equal to $50 \%$ of the mass of the granite $(111 \mathrm{~kg})$, transportation to the user was equal to $100 \%$ of the mass of granite $(222 \mathrm{~kg})$, the installation was equal to $100 \%$ of the mass of granite $(222 \mathrm{~kg})$, the use was equal to $100 \%$ of the mass of granite $(222 \mathrm{~kg})$, and the final disposal was equal to $50 \%$ of the mass of granite $(111 \mathrm{~kg})$.

It was assumed that the cabinet doors in all variants would be washed once a quarter (both sides), and the worktops would be washed daily. The same transportation distance to the customer was adopted in each variant, equalling $100 \mathrm{~km}$. Collective inventory tables for each life stage are presented below. Table 1 shows the mass $(\mathrm{kg})$ and costs of the materials $(€)$ for each furniture unit. Table 1 shows the cumulative mass of each furniture unit, without division into individual components or types of materials. Due to a large amount of data, it was decided to show these results in an aggregated form. However, it should be stressed that LCA and LCC were performed based on detailed information about the material consumption and the purchase costs for each, even minor construction elements (e.g., fronts, walls, screws, hinges, bolts, handles, joints, track rollers, drawers). These data were used to determine the environmental impact and the costs of production. More detailed information can be found in a separate file, 'Supplementary Information', where examples of the obtained results are presented. A description of the Microwave cabinet SM60/140 (BASE scenario) showed, in Table S10, where all construction elements are characterised in terms of theirs materials, mass, the environmental impact of the construction materials' production, and the prices. Table S11 presents the environmental impact of all furniture units from the perspective of characterised LCIA results for all impact categories. Also, the environmental impact related to the emission of greenhouse gases for producing various construction materials has been presented in the Supplementary Information (Table S12).

According to the data shown in Table 1, in the baseline scenario, all furniture units weigh $924 \mathrm{~kg}$, while double furniture units are the heaviest, including two storage cabinets $\$ 60 / 140(2 \times 62.5 \mathrm{~kg}=$ $125 \mathrm{~kg})$, two low corner cabinets SN120/90 $(2 \times 68.5 \mathrm{~kg}=137 \mathrm{~kg})$, two low storage cabinets SN60/90 $(2 \times 50.5 \mathrm{~kg}=101 \mathrm{~kg})$, the worktop $(103 \mathrm{~kg})$, and the modular cupboard $(96 \mathrm{~kg})$. As for the costs of purchasing materials and accessories, the same furniture units are a major source of costs, accounting for $66.5 \%$ of the whole system of furniture $(704 €+725 €+323 €+245 €=1998 €)$. In scenario ALT1, the cost of the entire system increases significantly from $3003 €$ to $4039 €$, compared to BASE, making a difference of $34 \%$. This is mainly due to the higher prices of solid wood boards in comparison to wood-based boards. ALT1 assumed a change of the construction material for all cabinet fronts and worktops, which, when of wood in the BASE scenario, together weigh $268 \mathrm{~kg}$, accounting for $29 \%$ of the entire system. In ALT1, the mass of these units is $246 \mathrm{~kg}$, which results mainly from the lower mass of the worktops (the HPL density used in BASE was $\mathrm{d}=1450 \mathrm{~kg} / \mathrm{m}^{3}$, while the density of hardwood used in ALT1 was $d=960 \mathrm{~kg} / \mathrm{m}^{3}$ ). The price of each furniture unit is clearly higher in ALT1, which results from the use of a more expensive material for the fronts. 
Table 1. Name, mass, and cost (as purchase price) of the furniture units for different scenarios of the designed kitchen (\% means the percentage of mass/cost).

\begin{tabular}{|c|c|c|c|c|c|c|c|c|c|c|c|c|c|}
\hline \multicolumn{14}{|c|}{ Furniture Units in Designed Kitchen } \\
\hline \multirow{3}{*}{$\begin{array}{c}\text { Name of } \\
\text { Furniture Unit }\end{array}$} & \multirow{3}{*}{ Symbol } & \multicolumn{4}{|c|}{ Baseline Scenario } & \multicolumn{4}{|c|}{ Alt1 Scenario } & \multicolumn{4}{|c|}{ ALT2a/b Scenario * } \\
\hline & & \multicolumn{2}{|c|}{ Mass } & \multicolumn{2}{|c|}{ Costs } & \multicolumn{2}{|c|}{ Mass } & \multicolumn{2}{|c|}{ Costs } & \multicolumn{2}{|c|}{ Mass } & \multicolumn{2}{|c|}{ Costs } \\
\hline & & {$[\mathrm{kg}]$} & {$[\%]$} & [€] & [\%] & {$[\mathrm{kg}]$} & {$[\%]$} & {$[€]$} & {$[\%]$} & {$[\mathrm{kg}]$} & {$[\%]$} & [€] & [\%] \\
\hline Dishwasher cabinet & $\mathrm{SZ60/140}$ & 41 & 4 & 72 & 2 & 42 & 5 & 107 & 3 & 41 & $\begin{array}{l}4(a) \\
5 \text { (b) }\end{array}$ & 358 & $\begin{array}{l}2 \text { (a) } \\
3(\mathrm{~b})\end{array}$ \\
\hline Fridge cabinet & SL60/140 & 41 & 4 & 79 & 3 & 42 & 5 & 127 & 3 & 41 & $\begin{array}{l}4 \text { (a) } \\
5 \text { (b) }\end{array}$ & 391 & $\begin{array}{l}3(\mathrm{a}) \\
3(\mathrm{~b})\end{array}$ \\
\hline Microwave cabinet & $\mathrm{SM} 60 / 140$ & 64 & 7 & 346 & 12 & 65 & 7 & 385 & 10 & 65 & $\begin{array}{l}6 \text { (a) } \\
7 \text { (b) }\end{array}$ & 1560 & $\begin{array}{l}10(\mathrm{a}) \\
11(\mathrm{~b})\end{array}$ \\
\hline $\begin{array}{l}\text { Storage cabinet } \\
\text { (2pcs.) }\end{array}$ & $\mathrm{S} 60 / 140$ & 125 & 14 & 704 & 23 & 130 & 14 & 820 & 20 & 127 & $\begin{array}{l}13(a) \\
14(b)\end{array}$ & 3174 & $\begin{array}{l}21(a) \\
23(b)\end{array}$ \\
\hline Oven cabinet & SP60/120 & 62 & 7 & 124 & 4 & 62 & 7 & 140 & 3 & 62 & $\begin{array}{l}6 \text { (a) } \\
7 \text { (b) }\end{array}$ & 587 & $\begin{array}{l}4(\mathrm{a}) \\
4(\mathrm{~b})\end{array}$ \\
\hline $\begin{array}{l}\text { Low corner cabinet } \\
(2 \text { pcs.) }\end{array}$ & SN120/90 & 137 & 15 & 725 & 24 & 142 & 16 & 848 & 21 & 139 & $\begin{array}{l}14(a) \\
16(b)\end{array}$ & 3267 & $\begin{array}{l}22(a) \\
23(b)\end{array}$ \\
\hline $\begin{array}{l}\text { Low storage cabinet } \\
\text { (2pcs.) }\end{array}$ & SN60/90 & 101 & 11 & 323 & 11 & 104 & 11 & 400 & 10 & 102 & $\begin{array}{l}10(a) \\
11(b)\end{array}$ & 1504 & $\begin{array}{l}10(\mathrm{a}) \\
11(\mathrm{~b})\end{array}$ \\
\hline Worktop & PRB180/60 & 103 & 11 & 75 & 3 & 83 & 9 & 165 & 4 & $\begin{array}{l}130(\mathrm{a}) \\
87(\mathrm{~b})\end{array}$ & $\begin{array}{l}13(a) \\
10(b)\end{array}$ & $\begin{array}{l}894 \text { (a) } \\
493 \text { (b) }\end{array}$ & $\begin{array}{l}6 \text { (a) } \\
4(\mathrm{~b})\end{array}$ \\
\hline $\begin{array}{c}\text { Mobile unit for } \\
\text { waste segregation }\end{array}$ & $\mathrm{MO} 40 / 60$ & 33 & 4 & 96 & 3 & 34 & 4 & 115 & 3 & 33 & $\begin{array}{l}3(a) \\
4(b)\end{array}$ & 422 & $\begin{array}{l}3 \text { (a) } \\
3(\mathrm{~b})\end{array}$ \\
\hline $\begin{array}{l}\text { Mobile unit with } \\
\text { drawers }\end{array}$ & MJ40/60 & 31 & 3 & 129 & 4 & 31 & 3 & 162 & 4 & 31 & $\begin{array}{l}3(a) \\
3(b)\end{array}$ & 564 & $\begin{array}{l}4(\mathrm{a}) \\
4(\mathrm{~b})\end{array}$ \\
\hline Modular cupboard & MULTI & 96 & 10 & 245 & 8 & 105 & 12 & 541 & 13 & 96 & $\begin{array}{l}10(a) \\
11(b)\end{array}$ & 1073 & $\begin{array}{l}7 \text { (a) } \\
8(\mathrm{~b})\end{array}$ \\
\hline $\begin{array}{c}\text { Mobile } \\
\text { worktop-sink }\end{array}$ & $\mathrm{BMZ}$ & 53 & 6 & 48 & 2 & 35 & 4 & 132 & 3 & $\begin{array}{l}78 \text { (a) } \\
\text { (39) b }\end{array}$ & $\begin{array}{l}8(a) \\
4(b)\end{array}$ & $\begin{array}{l}734 \text { (a) } \\
367 \text { (b) }\end{array}$ & $\begin{array}{l}5 \text { (a) } \\
3(\mathrm{~b})\end{array}$ \\
\hline $\begin{array}{l}\text { Mobile worktop- } \\
\text { induction hob }\end{array}$ & BMP & 40 & 4 & 36 & 1 & 26 & 3 & 99 & 2 & $\begin{array}{l}58 \text { (a) } \\
29(\mathrm{~b})\end{array}$ & $\begin{array}{l}6 \text { (a) } \\
3(\mathrm{~b})\end{array}$ & $\begin{array}{l}551(\mathrm{a}) \\
275 \text { (b) }\end{array}$ & $\begin{array}{l}4(\mathrm{a}) \\
2(\mathrm{~b})\end{array}$ \\
\hline
\end{tabular}


Table 1. Cont.

\begin{tabular}{|c|c|c|c|c|c|c|c|c|c|c|c|c|c|}
\hline \multicolumn{14}{|c|}{ Furniture Units in Designed Kitchen } \\
\hline \multirow{3}{*}{$\begin{array}{c}\text { Name of } \\
\text { Furniture Unit }\end{array}$} & \multirow{3}{*}{ Symbol } & \multicolumn{4}{|c|}{ Baseline Scenario } & \multicolumn{4}{|c|}{ Alt1 Scenario } & \multicolumn{4}{|c|}{ ALT2a/b Scenario * } \\
\hline & & \multicolumn{2}{|c|}{ Mass } & \multicolumn{2}{|c|}{ Costs } & \multicolumn{2}{|c|}{ Mass } & \multicolumn{2}{|c|}{ Costs } & \multicolumn{2}{|c|}{ Mass } & \multicolumn{2}{|c|}{ Costs } \\
\hline & & {$[\mathrm{kg}]$} & [\%] & [€] & {$[\%]$} & {$[\mathrm{kg}]$} & [\%] & {$[€]$} & [\%] & [kg] & {$[\%]$} & {$[€]$} & {$[\%]$} \\
\hline Total & & 924 & 100 & 3003 & 100 & 901 & 100 & 4039 & 100 & $\begin{array}{l}1002(a) \\
892(b)\end{array}$ & 1100 & $\begin{array}{l}3443(a) \\
3205(b)\end{array}$ & 100 \\
\hline \multicolumn{2}{|l|}{ Differences } & \multicolumn{4}{|c|}{$\begin{array}{c}\text { Cabinet fronts made of Medium } \\
\text { Density Fibreboard }\left(\mathrm{d}=770 \mathrm{~kg} / \mathrm{m}^{3}\right) \\
\text { Worktop (Prb180/60), Mobile worktop } \\
\text { sink (BMZ), Mobile worktop induction } \\
\text { hob (BMP) made of High-Pressure } \\
\text { Laminate }\left(\mathrm{d}=1450 \mathrm{~kg} / \mathrm{m}^{3}\right)\end{array}$} & \multicolumn{4}{|c|}{$\begin{array}{l}\text { Cabinet fronts made of hardwood } \\
\qquad\left(\mathrm{d}=960 \mathrm{~kg} / \mathrm{m}^{3}\right) \\
\text { Worktop (PRB180/60), Mobile worktop } \\
\text { sink (BMZ), Mobile worktop induction } \\
\text { hob (BMP) made of hardwood } \\
\quad\left(\mathrm{d}=960 \mathrm{~kg} / \mathrm{m}^{3}\right)\end{array}$} & \multicolumn{4}{|c|}{$\begin{array}{c}\text { Cabinet fronts made of Medium Density } \\
\text { Fibreboard }\left(\mathrm{d}=770 \mathrm{~kg} / \mathrm{m}^{3}\right) \\
\text { Worktop (PRB180/60), Mobile worktop sink } \\
\text { (BMZ), Mobile worktop induction hob (BMP) } \\
\text { made of granite }\left(\mathrm{d}=750 \mathrm{~kg} / \mathrm{m}^{3} \text { ) }\right. \\
\text { Additional furniture legs for cabinets on which } \\
\text { the granite top is installed (two additional } \\
\text { legs per one cabinet) }\end{array}$} \\
\hline
\end{tabular}

* In ALT2a and ALT2b, the furniture fronts are made of wood-based boards (lacquered Medium Density Fibreboard, their lifetime is 10 years, restoration by lacquering the fronts once a year); in ALT 2a, the worktops are made of granite (impregnation of the granite worktop once a year; lifetime is 10 years); in ALT2b, the worktops are made of granite (impregnation of granite once a year; lifetime is 20 years; additional legs for cabinets on which granite worktops are placed). 
The ALT2 scenario assumed the use of MDF fronts and $30 \mathrm{~mm}$ thick granite worktops (PRB180/60, BMZ, BMP) and additional legs for the cabinets on which worktops will be located. The mass of the entire system has gone up to $1002 \mathrm{~kg}$, while the cost of the system is estimated at $3443 €$ (variant ALT2a). The cost is lower than in the case of ALT1 due to the fact that the material of the cabinet fronts remained unchanged (less expensive MDF). The total mass of the worktops used in the BASE scenario is $195 \mathrm{~kg}$ (150 kg = HPL board, $45 \mathrm{~kg}$ = other elements); the hardwood worktops in ALT1 weigh $145 \mathrm{~kg}$ (100 kg = hardwood, $45 \mathrm{~kg}$ = other components), while those made of granite in ALT2 weigh $266 \mathrm{~kg}$ (221 kg = granite, $45 \mathrm{~kg}$ = other components). This has an impact not only on the total mass of the whole system, but also on the transportation coefficients.

Table 2 also presents data about the other stages of the life cycle, including transportation to the user (load mass, distance $=100 \mathrm{~km}$, transportation coefficients) and furniture installation at the user's location, which was calculated on the basis of the working time and the number of employees, the electricity consumed by electrical tools $(\mathrm{kWh}, €)$, and the remuneration of the employees. The slightly higher installation costs of the ALT2 kitchen stem from the assumption that an additional person is required for the installation of granite countertops. In scenarios BASE and ALT1, it has been assumed that the kitchen will be installed by two persons for eight hours, while the installation of the ALT2 kitchen will require three people working for six hours. This has no impact on the electricity consumption because the activities performed by the third person do not require a power supply (carrying, stacking). As for the use of the furniture, it has been demonstrated, both in terms of mass and cost, that water and detergent consumption is related to cleaning the kitchen and using preservatives such as lacquer for wood-based boards, oil for wood, and sealer for the granite worktops.

The last part of Table 2 shows the mass of the waste generated after the transfer of furniture for final disposal and the related costs. Since the costs are estimated from the point of view of the furniture user, the costs of the final disposal are presented as negative numbers (income). This is due to the fact that both recyclers and incineration plants pay furniture users for the delivery of waste. These costs were calculated by market resale prices in Poland at the time of the study. The lower economic benefit in scenario ALT2b is due to the fact that, in this scenario, it has been assumed that only $50 \%$ of the granite mass will be resold to the manufacturer of the aggregate (for reuse). 
Table 2. Inventory data for different life cycle stages of the designed kitchen.

\begin{tabular}{|c|c|c|c|c|c|c|c|c|c|c|c|}
\hline \multicolumn{12}{|c|}{ Furniture Transportation to the User } \\
\hline \multirow{2}{*}{ Scenario } & \multicolumn{2}{|c|}{ Load } & \multicolumn{2}{|c|}{ Distance } & \multicolumn{2}{|c|}{ Transport Indicator } & \multicolumn{2}{|c|}{ Cost (Fuel) } & \multicolumn{2}{|c|}{ Cost (Driver's Payment) } & Costs Per Life Cycle (Transport) \\
\hline & \multicolumn{2}{|c|}{$[\mathrm{kg}]$} & \multicolumn{2}{|c|}{$[\mathrm{km}]$} & \multicolumn{2}{|c|}{ [tkm] } & \multicolumn{2}{|c|}{ [€] } & \multicolumn{2}{|c|}{ [€] } & [€] \\
\hline BASE & \multicolumn{2}{|c|}{923} & \multicolumn{2}{|c|}{100} & \multicolumn{2}{|c|}{92} & \multicolumn{2}{|c|}{18.70} & \multicolumn{2}{|c|}{18.26} & 36.96 \\
\hline ALT 1 & & & \multicolumn{2}{|c|}{100} & \multicolumn{2}{|c|}{90} & \multicolumn{2}{|c|}{18.25} & \multicolumn{2}{|c|}{18.26} & 36.52 \\
\hline ALT2a & \multirow{2}{*}{\multicolumn{2}{|c|}{$\begin{array}{l}1,002 \\
892\end{array}$}} & \multirow{2}{*}{\multicolumn{2}{|c|}{$\begin{array}{l}100 \\
100\end{array}$}} & \multirow{2}{*}{\multicolumn{2}{|c|}{$\begin{array}{c}100 \\
89\end{array}$}} & & \multicolumn{2}{|c|}{18.26} & 38.57 \\
\hline ALT2b & & & & & & & \multicolumn{2}{|c|}{18.06} & \multicolumn{2}{|c|}{18.26} & 36.33 \\
\hline \multicolumn{12}{|c|}{ Furniture Installation At The Users' Accommodation } \\
\hline & & lectricity & onsumptic & & & Electri & ity Cost & & Cost $(W$ & ayment) & Costs Per Life cycle (Installation) \\
\hline Scenario & & & & & & & & & & & {$[\epsilon]$} \\
\hline BASE & & & & & & & & & & & 72.7 \\
\hline ALT 1 & & & & & & & & & & & 72.7 \\
\hline ALT2a & & & & & & & 9 & & & & 80.9 \\
\hline ALT2b & & & & & & & & & & & 80.5 \\
\hline & & & & & & Use Of Fur & iture $(10 \mathrm{Ye}$ & & & & \\
\hline & & Cle & ing & & & & & & & & \\
\hline Scenario & & & & & $\begin{array}{r}\text { Lacquer ( } \\
\text { Fronts) } \\
\text { Work }\end{array}$ & $\begin{array}{l}\text { Cabinets } \\
\text { Product + } \\
\text { nent) }\end{array}$ & $\begin{array}{c}\text { Oil (For } \\
\text { Cabinet } \\
\text { Product + }\end{array}$ & $\begin{array}{l}\text { Norktop + } \\
\text { (Price of } \\
\text { Payment) }\end{array}$ & $\begin{array}{r}\text { Impreg } \\
\text { Worktop) } \\
\text { Work }\end{array}$ & $\begin{array}{l}\text { Granite } \\
\text { Product + } \\
\text { nent) }\end{array}$ & Costs Per Life Cycle (Use) \\
\hline & {$[\mathrm{kg}]$} & [€] & {$[\mathrm{kg}]$} & [€] & {$[\mathrm{kg}]$} & {$[\epsilon]$} & {$[\mathrm{kg}]$} & {$[€]$} & {$[\mathrm{kg}]$} & {$[€]$} & [€] \\
\hline BASE & 715 & 0.65 & 4 & 9.3 & 7.54 & 756 & - & - & - & - & 766 \\
\hline ALT 1 & 715 & 0.65 & 4 & 9.3 & - & - & 7.5 & 847 & - & - & 857 \\
\hline ALT2a & 715 & 0.65 & 4 & 9.3 & 7.54 & 756 & - & - & 2.15 & 91.5 & 895 \\
\hline ALT2b & 715 & 0.65 & 4 & 9.3 & 7.54 & 756 & - & - & 2.15 & 91.5 & 895 \\
\hline & & & & Final & Disposal C & Furniture (A & cording To & e Of Waste I & aterial) & & \\
\hline Scenario & $\begin{array}{l}\text { Wood Ar } \\
\text { Material }\end{array}$ & $\begin{array}{l}\text { od-Based } \\
\text { neration) }\end{array}$ & $\begin{array}{l}\text { Metals } \\
\text { Aluminiv }\end{array}$ & $\begin{array}{l}\text { ecycling; } \\
\text { neration) }\end{array}$ & Plastics (I & cycling; AB & PE and rul & cineration) & & & Costs Per Life Cycle (Final Disposal) \\
\hline & & & & & & & & & & & {$[€]$} \\
\hline BASE & & & & & & & & & & & -41.26 \\
\hline ALT 1 & & & & & & & & & & & -40.67 \\
\hline ALT2a & & & & & & & 03 & & & & -44.33 \\
\hline ALT2b & & & & & & & 03 & & & & -41.81 \\
\hline
\end{tabular}




\section{Results}

\subsection{Costs and Environmental Impact per Life Cycle Stages}

The total cumulative environmental impact of the kitchen's life cycle in the baseline scenario BASE is $398 \mathrm{mPt}$ (Figure 3), while the undiscounted cumulative life cycle costs analysed from the point of view of the user in the BASE version are $3759 €$ (Figure 4). The change of material from wood-based boards to oiled solid wood (BASE $\rightarrow$ ALT1) for the cabinets and worktops has resulted in a decrease of the environmental impact by $14 \%$ (up to $342 \mathrm{mPt}$ ). In contrast to the LCC result, just like in ALT1, the undiscounted costs of such a change are estimated at $4886 €$, accounting for an increase of $30 \%$ compared to BASE (Figure 4). The introduction of granite as a material for worktops, without taking into account the benefits from its long life (BASE $\rightarrow$ ALT2a), generates an environmental impact for the entire life cycle equalling $484 \mathrm{mPt}$ and costs at $4326 €$. This is an increase of $21.8 \%$ and $15 \%$ in terms of environmental impact and costs, respectively, compared to BASE. After taking into account the environmental benefits arising from the 20-year lifespan of the granite worktop (50\% of production, $50 \%$ of final disposal) (ALT2a $\rightarrow$ ALT2b), the environmental indicator drops from 484 to $375 \mathrm{mPt}$, while the costs go down from $4326 €$ to $4090 €$.

From the environmental point of view, it can therefore be concluded that variants ALT1 and ALT2 $\mathrm{b}$ are the preferred options (ALT1 $=342 \mathrm{mPt}$ and ALT2 $\mathrm{b}=375 \mathrm{mPt}$ ). From the cost point of view, however, they are less favourable. While the total undiscounted LCC indicator for ALT2b is 4090€, about $331 €(9 \%)$ higher than the costs in scenario BASE, in the case of ALT1, it is $4886 €$, accounting for an increase in costs by 30\% compared to BASE (Figure S2 in the Supplementary Information).

From the point of view of the environmental impact of the various life stages, similar results have been obtained for all the analysed variants (Figure S3 in the Supplementary Information). In any case, the production of construction materials and accessories is the main source of the environmental impact $\left(\right.$ BASE $_{\text {prod }}=646 \mathrm{mPt}, \mathrm{ALT}_{\text {prod }}=596 \mathrm{mPt}, \mathrm{ALT}_{2} \mathrm{a}_{\text {prod }}=703 \mathrm{mPt}$, ALT2 $\left.\mathrm{b}_{\text {prod }}=666 \mathrm{mPt}\right)$. Transportation is in second place; however, its indicator is more than 10 times lower than the result for production $\left(\mathrm{BASE}_{\text {trans }}=63 \mathrm{mPt}, \mathrm{ALT} 1_{\text {trans }}=62 \mathrm{mPt}, \mathrm{ALT} 2 \mathrm{a}_{\text {trans }}=68 \mathrm{mPt}, \mathrm{ALT} 2 \mathrm{~b}_{\text {trans }}=61 \mathrm{mPt}\right)$. Even lower indicators have been achieved for installation and use; $18 \mathrm{mPt}$ and from 5-9 $\mathrm{mPt}$, respectively. An important environmental benefit has been demonstrated in the final disposal. The negative result of the indicator stems from the assumption that the steel components of the furniture are intended for recycling, which is discussed later in this article. It should be noted that the cumulative environmental benefit at the stage of final disposal amounts to $50 \%$ of the cumulative indicator for production.

The purchase of furniture is the main source of costs. As for the undiscounted costs generated throughout the life cycle, the purchase costs constitute approximately $80 \%$ of the cumulative life cycle cost indicator (Figure S4); after the discounting, this share is increased by a few percent (Figure S5). The cost indicators for the remaining life cycle stages are slightly different from the LCIA results. The share of transportation costs is significantly lower than its share in the environmental indicator and amounts to as little as $0.2 \%$ (Figures S4 and S5). The installation costs are at $0.3-0.5 \%$. From the cost point of view, the importance of the use stage clearly grows (costs of water, detergents, restoration, and maintenance of the area), amounting to approximately $20 \%$ of the cumulative life cycle cost indicator. The ratios of the environmental indicators for production and use are 81:1 (BASE), 117:1 (ALT1), 78:1 (ALT2a), and 74:1 (ALT2b), and the ratios of costs for these two stages are 4:1 (BASE), 5:1 (ALT1), 4:1 (ALT2a), and 4:1 (ALT2b). It is thus evident that, although use plays a fully negligible role in the environmental terms, it is much more important from the cost point of view.

The shares of final disposal are also different in the LCIA and LCC results. As stated before, the negative environmental indicator for this stage (environmental benefit) is nominally $50 \%$ of the environmental impact exerted by the production of construction materials. The economic benefits (money for the user of the furniture from the resale of waste-to-waste management entities) are much lower and represent only about $1 \%$ of the purchase price of the furniture. More information about the 
assumptions made in relation to the final disposal can be found in the Supplementary Information in Table S13.

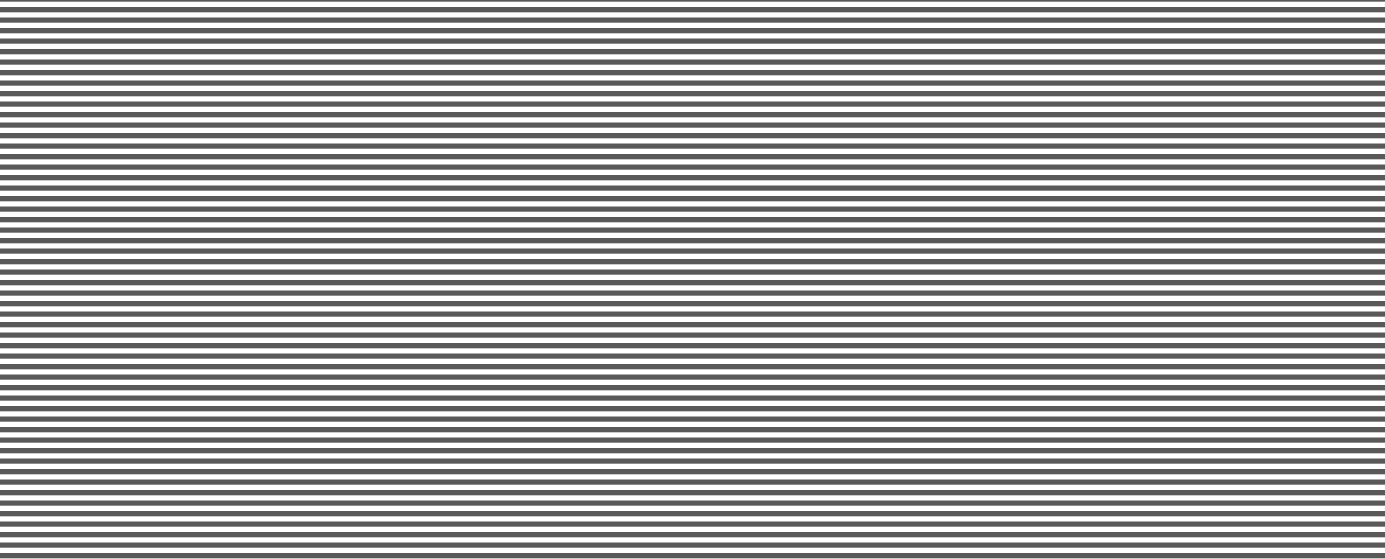

$\boxplus$ production $\square$ transport $\square$ instalation $\square$ use $\square$ final disposal $\quad \boxminus$ life cycle

Figure 3. Environmental impact of the life cycle stages and the entire life cycle (as aggregated result for all stages) for the designed kitchen (mPt) (Life Cycle Impact Assessment method: Impact 2002+, software: SimaPro Developer).

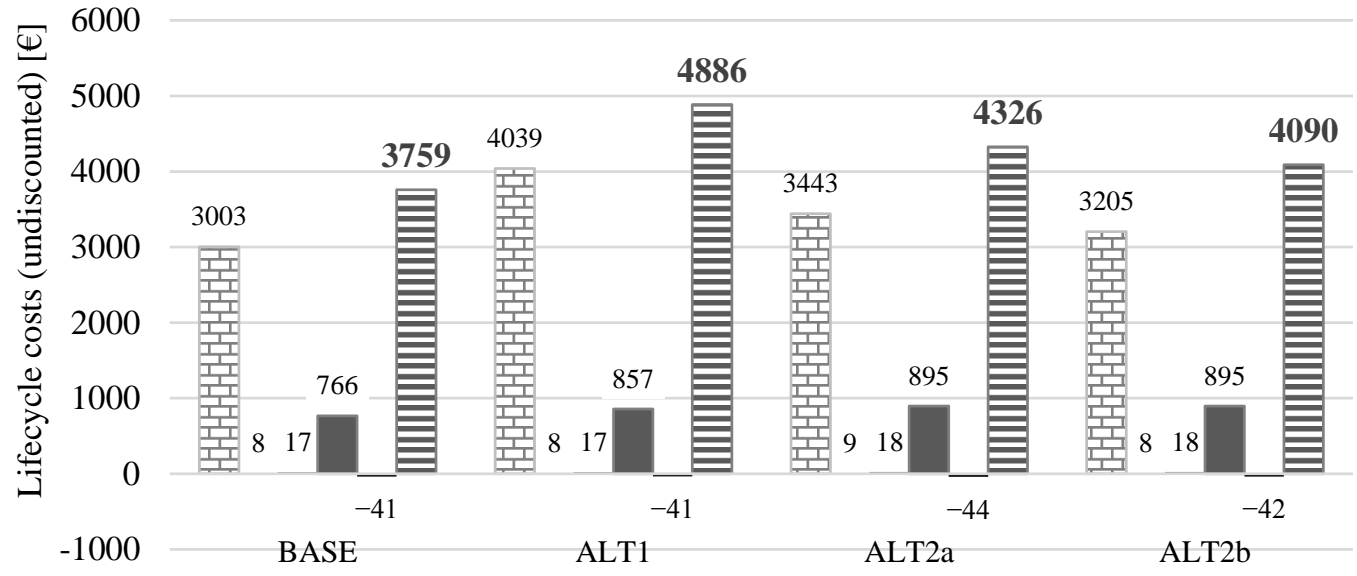

$\Xi$ production $\square$ transport $\square$ instalation $\square$ use $\square$ final disposal $\boxminus$ life cycle

Figure 4. Undiscounted costs per each life cycle stage and the entire life cycle (as aggregated result for all stages) of the designed kitchen $(€)$.

\subsection{Costs and Environmental Impact per Furniture Units and Construction Materials}

The values of the environmental indicators for individual furniture units are presented in Table 3, while their percentage shares in the impact of the production stage are included in the 
Supplementary Information (Table S1). The most severe environmental impact was obtained for the following furniture: the microwave cabinet SM60/140 (BASE $=74.3 \mathrm{mPt}$, ALT1 $=73.7 \mathrm{mPt}$, ALT2 $\mathrm{a}=77.6 \mathrm{mPt}, \mathrm{ALT} 2 \mathrm{~b}=77.6 \mathrm{mPt}$ ), the storage cabinet (two pieces) S60/140 (BASE $=145.8 \mathrm{mPt}$, $\mathrm{ALT} 1=143.9 \mathrm{Pt}, \mathrm{ALT} 2 \mathrm{a}=152.4 \mathrm{mPt}, \mathrm{ALT} 2 \mathrm{~b}=152.4 \mathrm{mPt}$ ), the low corner cabinet (two pieces) SN120/90 $($ BASE $=52.8 \mathrm{mPt}$, ALT1 $=50.9 \mathrm{mPt}$, ALT2a $=59.5 \mathrm{mPt}$, ALT2 $\mathrm{b}=59.5 \mathrm{mPt})$, the low storage cabinet (two pieces) SN60/90 (BASE $=102.1 \mathrm{mPt}, \mathrm{ALT} 1=100.9 \mathrm{mPt}, \mathrm{ALT} 2 \mathrm{a}=108.8 \mathrm{mPt}, \mathrm{ALT} 2 \mathrm{~b}=108.8 \mathrm{mPt}$ ), the mobile unit with drawers MJ40/60 (BASE $=64.9 \mathrm{mPt}$, ALT1 $=64.9 \mathrm{Pt}$, ALT2a $=64.9 \mathrm{mPt}$, $\mathrm{ALT} 2 \mathrm{~b}=64.9 \mathrm{mPt}$ ), the mobile unit for waste segregation MO40/60 (ALT1 $=64.9 \mathrm{Pt}, \mathrm{ALT} 2 \mathrm{a}=64.9 \mathrm{mPt}$, ALT2 $\mathrm{b}=64.9 \mathrm{mPt}$ ), and the modular cupboard $(\mathrm{BASE}=26.7 \mathrm{mPt}, \mathrm{ALT} 1=22.9 \mathrm{mPt}, \mathrm{ALT} 2 \mathrm{a}=26.7 \mathrm{mPt}$, $\mathrm{ALT} 2 \mathrm{~b}=26.7 \mathrm{mPt}$ ). In total, these modules are responsible for 72\% (BASE), 85\% (ALT1), 66\% (ALT2a), and $64 \%$ (ALT2b) of the environmental impact of the production stage.

Table 3. The environmental impact of the production of kitchen furniture units in various scenarios (mPt) (LCIA method: Impact2002+, software: SimaPro Developer).

\begin{tabular}{|c|c|c|c|c|c|}
\hline \multirow[t]{2}{*}{ Name Of Furniture Unit } & \multirow[t]{2}{*}{ Symbol } & $\begin{array}{l}\text { Baseline } \\
\text { Scenario }\end{array}$ & $\begin{array}{c}\text { ALT1 } \\
\text { Scenario }\end{array}$ & $\begin{array}{c}\text { ALT2a } \\
\text { Scenario }\end{array}$ & $\begin{array}{c}\text { ALT2b } \\
\text { Scenario }\end{array}$ \\
\hline & & {$[\mathrm{mPt}]$} & {$[\mathrm{mPt}]$} & {$[\mathrm{mPt}]$} & {$[\mathrm{mPt}]$} \\
\hline Dishwasher cabinet & SZ60/140 & 16.0 & 15.4 & 19.3 & 19.3 \\
\hline Fridge cabinet & SL60/140 & 20.1 & 19.3 & 23.4 & 23.4 \\
\hline Microwave cabinet & $\mathrm{SM} 60 / 140$ & 74.3 & 73.7 & 77.6 & 77.6 \\
\hline Storage cabinet (2pcs.) & $\mathrm{S} 60 / 140$ & 145.8 & 143.9 & 152.4 & 152.4 \\
\hline Oven cabinet & SP60/120 & 38.8 & 38.5 & 42.1 & 42.1 \\
\hline Low corner cabinet (2pcs.) & SN120/90 & 52.8 & 50.9 & 59.5 & 59.5 \\
\hline Low storage cabinet (2pcs.) & SN60/90 & 102.1 & 100.9 & 108.8 & 108.8 \\
\hline Worktop & PRB180/60 & 26.3 & 11.8 & 35.3 & 21.2 \\
\hline Mobile unit for waste segregation & $\mathrm{MO} 40 / 60$ & 47.6 & 47.3 & 47.6 & 47.6 \\
\hline Mobile unit with drawers & MJ40/60 & 64.9 & 64.9 & 64.9 & 64.9 \\
\hline Modular cupboard & MULTI & 26.7 & 22.9 & 26.7 & 26.7 \\
\hline Mobile worktop-sink & BMZ & 17.5 & 4.2 & 25.7 & 12.9 \\
\hline Mobile worktop-induction hob & $\mathrm{BMP}$ & 13.1 & 3.2 & 19.3 & 9.7 \\
\hline Total & & 646 & 596 & 703 & 666 \\
\hline
\end{tabular}

The modular cupboard MULTI is also mentioned above, although its environmental indicator is not very high. This is due to the fact that LCA and LCC did not take into account data concerning the cupboard hardware, which would otherwise raise both the environmental and cost indicators. The case of the low corner cabinet (two pieces) SN120/90 is similar as the LCA does not include a corner unit with full extension PEKA shelves. It is expected that the inclusion of this unit would further increase its indicators. These pieces of furniture units are also key components from the cost point of view (Table 1). Together, they constitute $82 \%$ (BASE), 81\% (ALT1), 76\% (ALT2a), and 75\% (ALT2b) of the entire purchase price of the furniture.

The full design and construction documentation was prepared for each designed furniture unit, enabling the production of the furniture by the manufacturer. The documentation included a technical description, technical requirements, and drawings, along with information about the dimensions, components, materials, and selected specific accessories. It can generally be assumed that the material structures of the designed cabinets are alike because they are constructed in a similar way. Tables S2 and S3 in the Supplementary Information present data about the mass of the individual furniture units by the types of construction materials for the BASE scenario. It can be seen (Table S2) that $88 \%$ of the mass of the entire kitchen in the BASE standard is wood-based materials $(812 \mathrm{~kg})$ and $9.8 \%$ is ferrous metals (steel) $(90.3 \mathrm{~kg}$ ). The wall cabinets, fronts, and horizontal worktops are composed of wood-based materials. The steel parts are mainly components of the drawer track guides (glides, actuators, fasteners) but are also slides, sides, and other accessories such as connections, hinges, bolts and screws.

A comparison of the values shown in Tables S2 and S3 for the columns corresponding to the microwave cabinet SM60/140, storage cabinet (two pieces) S60/140, low corner cabinet (two pieces) 
SN120/90, low storage cabinet (two pieces) SN60/90, mobile unit with drawers MJ40/60, mobile unit for waste segregation MO40/60, and the modular cupboard MULTI shows that these furniture units generally involve the greatest consumption of construction materials (the highest mass) and the heaviest steel components (microwave cabinet $19.4 \%$, storage cabinet $19.9 \%$, low storage cabinet $16.3 \%$, mobile unit with drawers $41 \%$ ). In the cases of the low corner cabinet and the modular cupboard, the share of metal parts would be higher if the cupboard hardware and the full extension of the PEKA shelf were taken into account.

\section{Discussion}

Wood-based materials constitute $88 \%$ of the mass of the furniture in the BASE scenario (Table S2), while their share in the costs is only $28 \%$ (Table S6) and their environmental impact is $30 \%$ (Table S4). Metal parts are only $10.5 \%$ of the mass of the furniture system, while their share in the total environmental impact is $67 \%$ and their share in the costs is $50 \%$. The high share of metal parts in the environmental impact is due to the assumption that the majority of furniture accessories are made of high-quality steel (according to the description of the material composition provided by the producers or sellers). The cumulative impacts of the production of $96.8 \mathrm{~kg}$ of metal components (steel $90.3 \%$, aluminium $6.5 \mathrm{~kg}$ ) is $431.6 \mathrm{mPt}$, of which steel is $415.3 \mathrm{mPt}$ and aluminium is $16.3 \mathrm{mPt}$. The analysis assumes that the steel parts are recycled after the use of the furniture at the stage of final disposal.

Figure 3 shows that environmental benefits are generated in each of the analysed scenarios at the stage of final disposal. In the BASE scenario, the final indicator for this stage is $-338 \mathrm{mPt}$ and stems mainly from recycled steel. The indicator for steel production in the amount consumed to construct the furniture in the BASE scenario is $415.3 \mathrm{mPt}$, while the environmental benefit from its recycling is $-375 \mathrm{mPt}$; the result has been obtained by treating the environmental impact of steel production as an avoided burden (environmental benefit) and subtracting from this the negative impacts associated with steel scrap collection and management, which represents $90 \%$ of the production impact. Thus, on the one hand, steel is the main source of the negative impact generated at the stage of production; on the other hand, it has significant recycling potential, being a source of environmental benefits. As for the costs, the benefit to the user from the resale of used steel components is small. The costs of purchasing steel components in the BASE scenario have been estimated at $1371.8 €$ (Table S6), while the revenue from their resale to a recycler is $17 €$, meaning that the purchase costs are refunded only at the level of $1.2 \%$.

The environmental impact of the production of wood-based materials, the consumption of which is nine times higher than that of steel (wood-based materials $812.1 \mathrm{~kg}$, steel $90.3 \mathrm{~kg}$ ), is more than two times lower than the impact of the production of steel components (wood-based materials $191.9 \mathrm{mPt}$, steel $415.3 \mathrm{mPt}$ ). However, it has been assumed that wood-based materials are not recyclable and would therefore be sent to incinerators for final disposal. Due to their structure (resins, binder), the incineration of wood-based materials generates a higher environmental impact than that of untreated wood. The environmental impact exerted by the incineration of $812.1 \mathrm{~kg}$ of wood-based materials has been estimated at $36.5 \mathrm{mPt}$. Thus, from the point of view of two key life cycle stages of wood-based materials and steel (production and final disposal), steel is much more advantageous, even though the cumulative effect of production is significantly higher per $1 \mathrm{~kg}$ of the material $(4.45 \mathrm{mPt} / 1 \mathrm{~kg}$ of steel, $0.22 \mathrm{mPt} / 1 \mathrm{~kg}$ of laminated chipboard, $0.25 \mathrm{mPt} / 1 \mathrm{~kg}$ of MDF). The production and incineration of wood-based materials generate a potential impact equal to $228.36 \mathrm{mPt}(191.9 \mathrm{mPt}+36.5 \mathrm{mPt})$, while the production and recycling of steel generate only $40.3 \mathrm{mPt}(415.3 \mathrm{mPt}+(-) 375 \mathrm{mPt})$.

Other scenarios should also be assessed in the context of these results. Tables S8 and S9 (Supplementary Information) present the environmental impact and costs of those items that vary in each scenario, i.e., cabinet fronts and worktops. In both cases, the analysis was made for different life cycle stages. Only two scenarios are considered for fronts: MDF fronts (restoration by lacquering during use) and solid hardwood fronts (restoration by oiling during use). Since the densities of these 
two materials are different (MDF $770 \mathrm{~kg} / \mathrm{m}^{3}$, hardwood $960 \mathrm{~kg} / \mathrm{m}^{3}$ ), the mass of the fronts in both variants is different. The MDF fronts weigh $118 \mathrm{~kg}$, and the wood fronts are $146 \mathrm{~kg}$, resulting in higher costs and environmental indicators for transportation. The production of solid wood fronts generates a much lower impact, equal to $18 \mathrm{mPt}$, while the MDF fronts generate $29 \mathrm{mPt}$. The analysis was based on data sets from the ecoinvent database, which is representative of Europe, with 'sawn timber, hardwood, planed, kiln dried, $\mathrm{u}=10 \%$, at plant, $\left(\mathrm{m}^{3}\right)^{\prime}$ and for board 'medium density fibreboard, at plant/RER $\left(\mathrm{m}^{3}\right)^{\prime}$.

The environmental impact of the production of $1 \mathrm{~m}^{3}$ of wood calculated using Impact 2002+ is $113.6 \mathrm{mPt}(0.118 \mathrm{mPt} / 1 \mathrm{~kg})$, while that of $1 \mathrm{~m}^{3}$ of $\mathrm{MDF}$ equals $196.9 \mathrm{mPt}(0.256 \mathrm{mPt} / 1 \mathrm{~kg})$. A reduction of impact occurs mainly in the damage categories 'resources' and 'climate change'. In the first case, the indicator for $1 \mathrm{~m}^{3}$ of wood is $13.7 \mathrm{mPt}$, while, for $1 \mathrm{~m}^{3}$ of $\mathrm{MDF}$, it is $74.4 \mathrm{mPt}$ (5.5 times higher). In relation to climate change, the indicator for $1 \mathrm{~m}^{3}$ of wood is $10.85 \mathrm{mPt}$, while, for MDF, it is $48.5 \mathrm{mPt}$, which is 4.5 times higher. The environmental benefit of wood is also visible in terms of 'human health' (26.7 mPt $/ 1 \mathrm{~m}^{3}$ of wood, while the indicator for human health for $1 \mathrm{~m}^{3}$ of MDF is $63.3 \mathrm{mPt}$, which is 2.4 times higher). While the wooden fronts are much more advantageous from an environmental point of view, they are much more expensive. The costs of purchasing wooden fronts are estimated at $1196 €$ and are three times more expensive than MDF fronts (396€). There is no significant difference between these two materials in terms of the costs of use and final disposal.

The use of wooden worktops is also the most beneficial in environmental terms (Tables S8 and S9 in the Supplementary Information). The impacts of production, transportation, use, and final disposal for wooden countertops are as follows: BASE $_{\text {worktops }} 68 \mathrm{mPt}$, ALT1 worktops $_{25} \mathrm{mPt}$, ALT2 $\mathrm{a}_{\text {worktops }}$ $92 \mathrm{mPt}$, and ALT2 $\mathrm{b}_{\text {worktops }} 55 \mathrm{mPt}$. If the benefits from the extended lifespan of granite worktops are not taken into account, this variant (ALT2) is the least advantageous. Halving the impacts of production and final disposal decreases the result to $55 \mathrm{mPt}$, which is comparable to BASE. Moreover, the costs of purchasing granite are higher than the purchase price of wooden worktops (476€ for granite worktops in ALT2a, $375 €$ for wooden worktops, and $139 €$ for HPL worktops). However, if their extended lifespan and only $50 \%$ of the purchase costs are taken into account, they are preferable to wooden worktops ( $238 €$ for granite countertops in ALT2b, $375 €$ for the wooden worktops).

Steel consumption did not differ between the analysed scenarios, but the ALT2 scenario has assumed an installation of an additional two legs on each of the cabinets on which granite countertops will be placed. For simplicity, it has been assumed that the legs consist only of steel. The additional steel consumption for the 18 additional legs has reached $6.8 \mathrm{~kg}$. With the significant disparities in the environmental impact of steel and wood materials (per $1 \mathrm{~kg}$ ), it turns out that the impact generated by the production of $6.8 \mathrm{~kg}$ of high alloyed steel is $30 \mathrm{mPt}$, and this indicator is comparable to the impact exerted by the production of all MDF fronts $(29 \mathrm{mPt})$ and much higher than the impact of the production of wooden fronts $(18 \mathrm{mPt})$. However, the recyclability of steel brings an environmental benefit of $-28 \mathrm{mPt}$, and eventually the combination of both values gives the environmental indicator for the additional legs equal to $2.5 \mathrm{mPt}$. From the cost point of view, the introduction of additional legs is much less significant (the cost of purchasing these additional legs is $92 €)$. While $30 \mathrm{mPt}$ for the production of $7 \mathrm{~kg}$ of steel accounts for $4.3 \%$ of the impacts exerted by the production of all construction materials in ALT2a, $92 €$ accounts for as little as $0.6 \%$ of the costs of purchasing these materials.

\section{Conclusions}

This article presents the results of LCA and LCC for different variants of the designed kitchen. In addition to environmental and cost aspects, this analysis also includes social issues, as dozens of design solutions have been developed to facilitate the use of the kitchen by the elderly and physically disabled. As shown in Figure S2 (Supplementary Information), no variant of the design is clearly preferable. All kitchens have the same social solutions (each variant has 24 design solutions taking into account the needs of the elderly and physically disabled). From an environmental point of view, in terms of the whole life cycle, ALT1 is the most advantageous variant and assumes the use 
of solid wood fronts and countertops. However, this is also the most expensive design because the undiscounted life cycle costs have been estimated at $4886 €$, which is $30 \%$ higher than the BASE variant and 13\% higher than ALT2a, which assumes the use of expensive granite worktops (the ratios for the discounted costs are similar).

Based on the results, the following conclusions can be drawn. The analysis of the design solutions from the point of view of several criteria (costs, environmental impact, social aspects) and several life cycle stages shows the complexity of the decision-making process and difficulties in selecting a clearly favourable solution. Environmentally preferred materials may be difficult for users to accept due to their costs. On the other hand, materials that have a high environmental impact at the production stage may show a great potential for final disposal (reuse, recycling), which affects their final assessment in the context of the whole life cycle (e.g., steel). The assumed use of additional steel legs for cabinets supporting granite worktops in ALT2a and ALT2b shows that such seemingly trivial components may be important, at least from the environmental point of view. If steel was not recyclable, the introduction of additional legs would noticeably increase the environmental impact of the kitchen in variants ALT2a and ALT2b.

The long lifespan of materials must also be taken into account. In accordance with the Design for Durability principle, extending the service life is consistent with the idea of eco-design. In this analysis, the extended durability of granite countertops changes the ranking of the kitchen. While ALT2a scores the worst from the environmental point of view, ALT2b is in second place (following ALT1 in environmental terms and BASE in terms of costs). The issue of this discussion is how to account for the extended durability of materials and products. In the case of the analysed kitchen, ALT2b, only granite, as one of the components, is characterized by a 20-year period of use, while the other kitchen units have a 10-year lifespan.

The integrated kitchen presented in the paper is universal, which means that it can be used by people with or without disabilities. An increase in material usage is the main effect of introducing the integrative adaptations. For this reason, it is probable that the extension of the function results in an increase of the environmental impact and costs in comparison with a non-integrated kitchen. In the presented case, the additional materials are intended to be applied as a consequence of using a special lifting system for the worktops, a special steel/aluminium frame for the modular cupboard with an electric drive, and an additional supporting system for doors and drawers. Moreover, the construction of the furniture and its placement in the integrated kitchen must guarantee that additional free space is available (e.g., below the worktops to accommodate a wheelchair, tall plinths). An additional kitchen surface is also needed in order to gain a wheelchair manipulation zone (a field of $150 \mathrm{~cm}$ in diameter for convenient wheelchair manipulation is recommended). On the other hand, all solutions designed for the integrated kitchen are intended to reduce the risk of accidents and damage to the furniture. From this point of view, the adaptations can improve the durability of the kitchen.

Supplementary Materials: The following are available online at www.mdpi.com/2071-1050/9/8/1329/s1, Figure S1: Discounted costs per life cycle stages of the designed kitchen $(€)$; Figure S2: Comparison of the social, environmental, and cost results for the analysed kitchen scenarios; Figure S3: Comparison of the social, environmental, and cost results for the analysed kitchen scenarios; Figure S4: Share of the kitchen's life cycle stages in life cycle costs (undiscounted) (\%); Figure S5: Share of the kitchen's life cycle stages in life cycle costs (discounted) (\%). Table S1: Share of the kitchen's furniture units in the environmental impact of production (eco-indicator for production is 100\%) (\%); Table S2: Mass of the construction materials used in particular furniture units in the BASE scenario $(\mathrm{kg})$; Table S3: Share of the construction materials in the total mass of particular furniture units in the BASE scenario (\%); Table S4: Environmental impact of the construction materials for particular furniture units in the BASE scenario $(\mathrm{mPt})$; Table S5: Environmental impact of the construction materials as a share in the eco-indicator for particular furniture units in the BASE scenario (\%); Table S6: Costs of purchasing the construction materials for particular furniture units in the BASE scenario $(€)$; Table S7: Costs of purchasing the construction materials as a share in the total costs for particular furniture units in the BASE scenario (\%); Table S8: Environmental impact $(\mathrm{mPt})$ per life cycle stage and mass $(\mathrm{kg})$ of the fronts, worktops, and additional furniture legs in the analysed scenarios; Table S9: Costs $(€)$ per life cycle stage and the mass (kg) of the fronts, worktops, and additional furniture legs in the analysed scenarios; Table S10: Environmental impact of the production of the construction materials $(\mathrm{mPt})$ and the prices of construction elements $(€)$ of the microwave cabinet SM60/140 (BASE scenario); Table S11: Share of the furniture units in the characterised impact category indicator results 
(\%); Table S12: Cradle to gate environmental impact for the production of the construction materials as global warming (midpoint) and climate change (endpoint) indicator results; Table S13: Final disposal of wasted furniture units, including the type of waste, manner of treatment, and cost calculation.

Acknowledgments: The results presented in this article were obtained as a part of the project titled 'New Product Lines Enhancing Mobility and Accessibility of Environment for Seniors and Disabled financed by the Polish National Centre for Research and Development (NCBR). Within the framework of the project, the team has developed innovative products within every one of the designed product groups (technical transportation means, technical rehabilitation means, kitchens with technical environments), resulting in five patent applications owned by the project executors as well as prizes awarded to the designed products at the World Exhibition of Inventions, Research and New Technologies Innova 2013 in Brussels and at the Invention and New Products Exposition (INPEX) 2014 in Pittsburgh.

Author Contributions: Bogdan Baranowski conceived and designed the experiments, Anna Lewandowska and Przemysław Kurczewski performed the experiments (LCA), Katarzyna Joachimiak-Lechman performed the experiments (LCC), Anna Lewandowska and Przemysław Kurczewski analysed the data, Jarosław Selech and Marek Zablocki verified the data and consulted the results, and Anna Lewandowska wrote the paper.

Conflicts of Interest: The authors declare no conflict of interest. The founding sponsors had no role in the design of the study; in the collection, analyses, or interpretation of data; in the writing of the manuscript; or in the decision to publish the results.

\section{References}

1. Branowski, B.; Głowala, S.; Pohl, P.; Gabryelski, J.; Zabłocki, M. Badania ergonomiczne przestrzeni manipulacji seniorów i osób z niepełnosprawnościami (the ergonomic research on the manipulation space of the seniors and people with disabilities). In Projektowanie dla Seniorów i Osób Niepetnosprawnych. Badania. Analizy. Oceny. Konstrukcje; Baranowski, B., Ed.; Wydział Maszyn Roboczych i Transportu Politechniki Poznańskiej: Poznań, Poland, 2015; pp. 123-155. ISBN 978-83-941828-0-9.

2. Branowski, B. (Ed.) Projektowanie dla Seniorów i Osób Niepetnosprawnych. Badania. Analizy. Oceny. Konstrukcje (A Design for Seniors and Disabled People. Studies. Analyses. Assessments. Constructions); Wydział Maszyn Roboczych i Transportu Politechniki Poznańskiej: Poznań, Poland, 2015; p. 486. ISBN 978-83-941828-0-9.

3. Kilian, M. Starzenie się społeczeństw wyzwaniem dla współczesnego świata (aging societies phenomena as a challenge for the contemporary world). Praca Socjalna 2010, 1, 21-34.

4. United Nations. World Population Ageing: 1950-2050 (No. ST/ESA/SER.A/207). New York, 2011. Available online: www.un.org/esa/population/publications/worldageing19502050/pdf/preface_web.pdf (accessed on 10 June 2017).

5. Carse, B.; Thomson, A.; Stansfield, B. Use of biomechanical data in the Inclusive Design process: Packaging design and the older adult. J. Eng. Des. 2010, 21, 289-303. [CrossRef]

6. Chavalkul, Y.; Saxon, A.; Jerrard, R.N. Combining 2D and 3D design for novel packaging for older people. Int. J. Des. 2011, 5, 43-58.

7. Thomson, A.; Carse, B.; Stansfield, B. Design Requirements and the Older Adult. In Proceedings of ICED 2007, the 16th International Conference on Engineering Design, Paris, France, 28-31 July 2007. Available online: www.designsociety.org/publication/25760/design_requirements_and_the_older_adult (accessed on 10 June 2016).

8. Damodaran, L.; Olphert, C. Sustaining IT use by older people to promote autonomy and independence. Gerontechnology 2010, 9, 96-97. [CrossRef]

9. Emiliani, P.L. New technologies and services for disabled and elderly people in the emerging information society. In Computers Helping People with Special Needs; Miesenberger, K., Klaus, J., Zagler, W., Eds.; Springer: Linz, Austria, 2002; pp. 49-57. ISBN 978-3-540-43904-2.

10. Lim, C.S.C. Designing inclusive ICT products for older users: Taking into account the technology generation effect. Int. J. Des. 2010, 21, 189-206. [CrossRef]

11. Morris, J.; Mueller, J.; Jones, M. Tomorrow's elders with disabilities: What the wireless industry needs to know. Int. J. Des. 2010, 21, 131-146. [CrossRef]

12. Rosenbloom, S. Sustainability and automobility among the elderly: An international assessment. Transportation 2011, 28, 375-408. [CrossRef]

13. Yang, J.; Coughlin, J.F. In-Vehicle Technology for Self-Driving Cars: Advantages and Challenges for Aging Drivers. Int. J. Autom. Technol. 2014, 15, 333-340. [CrossRef] 
14. International Organization for Standardization. ISO/TR 14062:2002. Environmental Management-Integrating Environmental Aspects into Product Design and Development; International Organization for Standardization: Geneva, Switzerland, 2002.

15. Lofthouse, V. Investigation into the role of core industrial designers in ecodesign projects. Des. Stud. 2004, 25, 215-227. [CrossRef]

16. Akermark, A.M. Design for Environment from the Designers' Perspective. Proceedings, ECOD Esign 99: First International Symposium on Environmentally Conscious Design and Inverse Manufacturing, Tokyo, Japan, 1-3 February 1999; pp. 47-50.

17. Todd, J.A.; Curran, M.A. Streamlined Life-Cycle Assessment: A Final Report from SETAC North America, Streamlined LCA Workshop; Society of Environmental Toxicology and Chemistry (SETAC): Pensacola, FL, USA, 1999.

18. Soriano, V.J.A. Simplified Assessment Methodology to Environmentally Sound Product Design. In Proceedings of the Fifth Pacific Industrial Engineering and Management Systems Conference, Gold Coast, Australia, 12-15 December 2004.

19. Wimmer, W.; Zust, R.; Lee, K.M. Ecodesign Implementation: A Systematic Guidance on Integrating Environmental Considerations into Product Development; Springer: Berlin/Heidelberg, Germany, 2004.

20. Sousa, I.; Wallace, D. Product Classification to Support Approximate Life-Cycle Assessment of Design Concepts. Technol. Forecast. Soc. Chang. 2006, 73, 228-249. [CrossRef]

21. Joachimiak-Lechman, K. The Modification of the Life Cycle Assessment Methodology in the Context of Small and Medium-Sized Enterprises. Ph.D. Thesis, Faculty of Commodity Science, Poznan University of Economics and Business, Poznan, Poland, 2016.

22. ISO. ISO 14040:2006 Environmental Management_Life Cycle Assessment_Principles and Framework; ISO: Geneva, Switzerland, 2006.

23. Guinee, J.B.; Heijungs, R.; Huppes, G.; Zamagni, A.; Masoni, P.; Buonamici, R.; Ekvall, T.; Rydberg, T. Life Cycle Assessment: Past, Present and Future. Environ. Sci. Technol. 2011, 45, 90-96. [CrossRef] [PubMed]

24. Gluch, P.; Baumann, H. The Life Cycle Costing (LCC) Approach: A Conceptual Discussion of Its Usefulness for Environmental Decision-Making. Build. Environ. 2004, 39, 571-580. [CrossRef]

25. PN-EN 60300-3-3:2006. Dependability Management. Application Guide. Life Cycle Costing; International Electrotechnical Commission: Geneva, Switzerland, 2004.

26. Hunkeler, D.; Lichtenvort, K.; Rebitzer, G. Environmental Life Cycle Costing; CRC Press: Boca Raton, FL, USA, 2008.

27. Swarr, T.E.; Hunkeler, D.; Klopffer, W.; Pesonen, H.L.; Ciroth, A.; Brent, A.C.; Pagan, R. Environmental Life Cycle Costing: A Code of Practice; SETAC: New York, NY, USA, 2011.

28. Heijungs, R.; Settanni, E.; Guinee, J. Toward a Computational Structure for Life Cycle Sustainability Analysis: Unifying LCA and LCC. Int. J. Life Cycle Assess. 2013, 18, 1722-1733. [CrossRef]

29. Kronenberg, J.; Bergier, T. Sustainable development in a transition economy: Business case studies from Poland. J. Clean. Prod. 2012, 26, 18-27. [CrossRef]

30. Schau, E.M.; Traverso, M.; Finkbeiner, M. Life cycle approach to sustainability assessment: A case study of remanufactured alternators. J. Remanuf. 2012, 2, 1-14. [CrossRef]

31. Hu, M.; Kleijn, R.; Bozhilova-Kisheva, K.P.; Di Maio, F. An Approach to LCSA: The Case of Concrete Recycling. Int. J. Life Cycle Assess. 2013, 18, 1793-1803. [CrossRef]

32. Simoes, C.L.; Costa Pinto Ligia, L.M.; Simoes, R.; Bernardo, C.A. Integrated Environmental and Economic Life Cycle Analysis in Product Development: A Material Selection Case Study. Int. J. Life Cycle Assess. 2013, 18, 1734-1746. [CrossRef]

33. Lindahl, M.; Sundin, E.; Sakao, T. Environmental and Economic Benefits of Integrated Product Service Offerrings Quantified with Real Business Cases. J. Clean. Prod. 2014, 64, 288-296. [CrossRef]

34. Sakao, T.; Lindahl, M. A Method to Improve Integrated Product Service Offerings Based on Life Cycle Costing. CIRP Ann. Manuf. Technol. 2015, 64, 33-36. [CrossRef]

35. Kirvesoja, H.; Väyrynen, S.; Häikiö, A. Three evaluations of task-surface heights in elderly people's homes. Appl. Ergon. 2000, 31, 109-119. [CrossRef]

36. Gałązka, M.; Kromka-Szydek, M. Mieszkanie osoby niepełnosprawnej-przegląd nowoczesnych rozwiązań (accessible accommodation-A review of modern solutions). Aktual. Probl. Biomech. 2011, 5, 41-44. 
37. Fabisiak, B.; Kłos, R. Comparative analysis of difficulty of activities performed in kitchen by people aged 40-60 and over 60 years with visual impairment in the context of furniture design. Ann. Wars. Univ. Life Sci.-SGGW For. Wood Technol. 2012, 77, 216-221.

38. Hrovatin, J.; Širok, K.; Jevšnik, S.; Oblak, L.; Berginc, J. Adaptability of Kitchen Furniture for Elderly People in Terms of Safety. Drv. Ind. 2011, 63, 113-120.

39. Bonenberg, A. Shaping an integrating kitchen space with gesture-based control system. In Proceedings of the 7th International Conference on Universal Access in Human-Computer Interaction (UAHCI) 2013, Las Vegas, NV, USA, 21-26 July 2013; Springer: Berlin/Heidelberg, Germany.

40. Kłos, R.; Fabisiak, B.; Kaczmarek, M. Analysis of human needs in kitchen design for people with visual impairment. DronaIndustrija 2014, 65, 43-50. [CrossRef]

41. Maguire, M.; Peace, S.; Nicolle, C.; Marshall, R.; Sims, R.; Percival, J.; Lawton, C. Kitchen living in later life: Exploring ergonomic problems, coping strategies and design solutions. Int. J. Des. 2014, 8, 73-91.

42. Design Guide Kitchen. Pressalit A/S. 2015. Available online: www.e-pages.dk/pressalitcare/138/ (accessed on 9 June 2017).

43. McDonald, M. Sustainability in the Manufacturing of Kitchen and Bathroom Cabinets; International Specialised Skills Institute: Melbourne, Australia, 2011. Available online: www.issinstitute.org.au (accessed on 9 June 2017).

44. Oblak, L.; Jost, M. Methodology for Studying the Ecological Quality of Furniture. DronaIndustrija 2011, 62, 171-176. [CrossRef]

45. Nitkiewicz, T. Rola Ekologicznej Oceny Cyklu Życia We Wdrażaniu Zintegrowanej Polityki Produktowej (The Role of the Environmental Life Cycle Assessment in Implementation of Integrated Product Policy); Scientific Papers of Cracow University of Economics; Cracow University of Economics: Cracow, Poland, 2012; pp. 107-129.

46. Jolliet, O.; Margni, M.; Charles, R.; Humbert, S.; Payet, J.; Rebitzer, G.; Rosenbaum, R. IMPACT 2002+: A new life cycle impact assessment methodology. Int. J. Life Cycle Assess. 2003, 8, 324-330. [CrossRef]

(C) 2017 by the authors. Licensee MDPI, Basel, Switzerland. This article is an open access article distributed under the terms and conditions of the Creative Commons Attribution (CC BY) license (http:/ / creativecommons.org/licenses/by/4.0/). 